\title{
Postcolonial Resistance of Western Imperialist Ideology: Constructing Identities of Others as Violent Savages
}

\author{
Menia Mohammad Almenia \\ Department of English Language and Translation \\ College of Arabic Language and Social Sciences \\ Qassim University \\ Buraidah, Saudi Arabia
}

\begin{abstract}
This paper examines how hegemonic discourse, or the ideology of a dominant society has essentialized, fixed, and divided identities through the construction of binary division of Western's ideology as civilized and Others as savages. The development of postcolonial theory will be introduced with special consideration to Said's (1995) theory of Orientalism and Spivak's (1988) concept of "silencing the Others." Sample Western literary texts will show a concerted expression of colonial ideology supporting the concept of binary divisions. These will include The Tempest by William Shakespeare (1990), Robinson Crouse by Daniel Defoe (1899), Jane Eyre by Charlotte Bronte (2001), and Passage to India by E. M. Foster (1985). In contrast, literary works by minority authors, mainly postcolonialists, will be examined and considered according to how effectively they resist Western imperialist ideology.
\end{abstract}

Keywords: constructing, identities, ideology, others, postcolonial

Cites as: Almenia, M. M. (2018). Postcolonial Resistance of Western Imperialist Ideology:

Constructing Identities of Others as Violent Savages. Arab World English Journal for

Translation \& Literary Studies, 2 (4). $130-143$.

DOI: http://dx.doi.org/10.24093/awejtls/vol2no4.9 


\section{Introduction}

When we think of our world today and how some inferior nations are overwhelmed with tension, aggression, and violence, we may feel, as intellectuals in humanities, that we have a responsibility of reviewing and reexamining world policies and systems that influence these nations. The leaders of world system today proclaimed that they seek freedom, democracy, and human rights, but we see their actions usually contradict their declarations. If we look at history, we may find that arrogance, dictatorship, humiliation, and oppression of the weaker nations by the exploitation of their land and their wealth has constructed hatred and tension within and among these Third World nations. Therefore, weaker nations today have no language to call for justice and equality except a language of aggression and violence. A theoretical argument here may offer an understanding of this situation and some ideas for more equality alongside the overwhelming power and influence of Western popular culture and state ideological apparatus that continually reinforce complacency in response to the status quo.

This paper aims to identify how the hegemonic discourse, or the ideology of a dominant society has essentialized fixed and divided identities through the construction of binary division of Western's ideology as civilized and Others or violent savages. I will present my discussion here in three parts. First, postcolonial theory will be reviewed as an essential background for considering the subject. In particular, Edward Said's (1993) theory of Orientalism and Spivak's (1988) concept of the "Subalterns" will be discussed. This will provide a means to understand how representative English literary texts written by Western authors, such as The Tempest by William Shakespeare, Robinson Crouse by Daniel Defoe, Jane Eyre by Charlotte Bronte, and Passage to India by E. M. Foster convey Eurocentric ideologies about identity based on race. While postcolonial critics do their part to respond to such representation, minority authors also provide answers in examples of Third World literature. This paper's argument is that the success or failure of these minority authors rests in their ability to resist the ideology represented in the works of Western authors. The ability to resist hegemonic discourse, in representing the what postcolonial theory demonstrates, is necessary for breaking the cycle of replicating hierarchies of power between peoples.

\section{Literature Review}

Patrick Colm Hogan's (2000) discusses the nature of postcolonial literature, cautioning that scholars should not neglect the fundamental division of recognizing Third World literature and the White Eurocentric literatures. The ideology of dividing two societies, dominant and dominated, allow postcolonial literature to be introduced in a sense of two literatures; as Hogan (2000) argues that, "one arising from the dominant or colonizer society, the other from the dominated or colonized society" (p. 3). Based on Hogan's argument, postcolonial literature represents two literatures; one is written by the members of the oppressor society and the other is written by the members of the oppressed society. Hogan (2000) explains how postcolonial literature is classified as, "within the dominant group, we have already distinguished indigenous and alienated peoples. We may isolate two roughly parallel categories within the oppressor group: 1) metropolitan writers - English writers, in the case of Anglophone literature - and 2) settlers and Creoles" (p. 3). 
Recognizing both groups, oppressor and oppressed, have significant portrayal and interpretation of violence that is usually discussed in postcolonial literature studies.

Theorists such as Frantz Fanon (1963), Albert Memmi (2013), Aime Césaire (1984), Antonio Gramsci (1971), Edward Said (1995) and Neil Lazarus (2011) with many others portray and postulate that violence is a significant paradigm among postcolonial studies. When we look at the relation between the oppressor and the oppressed, we may find that there is a tension in between that leads to the acts of violence, but how does that happen? Fanon (1963) discusses in his book, The Wretched of the Earth, how the colonizer meets the colonized. Fanon mentions that, "[t]heir first encounter was marked by violence and their existence together - that is to say the exploitation of the native by the settler" (p. 36). Fanon's argument shows that the colonizers are the source of violence in the first part, and therefore, the colonized may use the same act of violence, which justifies their response to the colonized.

Another postcolonial theorist also agrees with Fanon's argument about who has triggered the act of violence. Memmi (2013) discusses that the relation between the colonizer and the colonized is initiated by violence. Memmi asserts that, "[c]olonialism denies human rights to human beings whom it has subdued by violence and keeps them by force in a state of misery and ignorance that Marx would rightly called a subhuman condition" (p. xxiv). A mode of racism and superiority is part of the colonialist methods, in which human rights does not apply. In addition Césaire (1984) describes this relation saying that, "whenever there are colonizers and colonized face to face, I see force, brutality, cruelty, sadism, conflict... No human contact, but relation of domination and submission" (p. 21). Based on Memmi and Césaire's arguments, the paradigm of violence as initiated by the oppressor may be justified by the claim of being superior to the oppressed, which are counted as a subhuman. Therefore, this article will discuss how the colonizers, or the dominant societies construct their superiority over the subordinate societies that were essentialized as violent savages.

Postcolonial theory has been influenced by the concept of cultural hegemony that was introduced by Gramsci (1971) and translated to the meaning of the success of the dominant classes to present their view of the world in a way that should be accepted by the other classes as "common sense" (p. 173). This way of only viewing the world as historical reality is discussed by Gramsci to represent the ideology of the White supremacy, through which the dominant cultures can essentialize their superiority over the other nations.

Based on Gramsci's (1971 concept of the cultural hegemony, Edward Said (1995) is one of the postcolonial theorists who responded to the fixity of the hegemonic discourse in his masterwork, Orientalism. Said writes and speaks to change the way of seeing a fixed division between the East and the West. Said understands the relationship between the Orient and the Occident is greatly affected by the interventions of European imperialism, which represents his theory.

Arab World English Journal for Translation \& Literary Studies 
Said's (1995) theory investigates how the Occident created the Orient and the consequences of this understanding. In Said's words, "[t]he orient was almost a European invention, and had been since antiquity a place of romance, exotic beings, haunting memories and landscapes, remarkable experiences" (p. 42). He is also critical of how the European visitor of the Orient is highly disappointed when he or she does not find the Orient with its European representation. According to Said (2003), the Orient became Europe's "deepest and most recurring images of the Other" (p. 42). One of the most crucial parts of the study of Orientalism is the freedom of the Other versus the agency of the ideology of the Western colonizer. Said explains how the Western hegemonic structure was conceived that, "Orientalism was ultimately a political vision of reality whose structure promoted the difference between that familiar (Europe, the West, 'us') and the strange (the Orient, the East, 'them') (p. 42). Said (2003) suggests that the duality thus created is false, both representing manufactured images reflecting one another (pp. 43-44). Therefore, Said (2003) argues that "the Orient was not (and is not) a free subject of thought or action" (p. 44) and he refers the reason to what he calls Orientalism.

Said's (2003) theory is a controversial approach that can assist the explication of Eurocentric discourse in relation to the Orient as he points out that, "the hegemonism of possessing minorities ... are accompanied by europocentrisim in the area of human and social sciences, and more particularly in those direct relationship with non-European people" (p. 97). In other words, Said describes that the Orient, through being possessed, has remained fixed through time and space for the West. Therefore, Said (2003) believes that, "so impressive have the descriptive and textual success of Orientalism been that entire periods of the Orient's cultural, political, and social history are considered mere responses to the West" (pp.108-9). In this view, Said identifies how the West has been coded as active, the Orient as passive (p. 109). To apply Said's theory, we need to identify how Western authors throughout several historical periods maintain representations of fixed identities for the Orient that emphasize the Western paradigm of violence as a theme that represents the minor characters among the selected representative literary texts as being violent uncivilized savages.

When we think of postcolonial studies that emerge as an institution, we should not neglect the historical transitions that we have gone through up to the moment. In his book, The Postcolonial Unconscious, Neil Lazarus (2011) introduces the developments of the field in a way that he calls "Periodisation" that offers an intellectual genealogy of postcolonial studies (p. 1). The first period starts from the post-1945 until the beginning of the 1970s. Lazarus (2011) describes this period as one of "explosive global economic growth accompanied, in the core capitalist countries, by an historically unprecedented demonstration of social resources" (p.2). At the same time, Lazarus (2011) notes that the subject, so-called Third World, became characterized by protest against colonization and for self-determination (p. 2). Direct colonization by the dominant countries has marked this period, and, therefore, postcolonial studies became articulated that time, emerging as a response to what has been rationalized by the colonial imperialist policies as a civilization mission.

Lazarus (2011) describes this response as:

Arab World English Journal for Translation \& Literary Studies 
$[t]$ he articulation and elaboration of national consciousness; the mobilization of popular will or support; the tempering of this will in the fire of the anticolonial campaigns; of campaigns for national liberation, when the least response of the colonial powers was intransigence and the arrogant refusal. (p. 3)

Such refusal triggers the silent masses to response through violence as an act of resistance to the colonial domination. Therefore, postcolonial literature portrays several Third World nations, like Kenya and Algeria and others, that went through bloody wars where millions were killed in the name of social freedom and national liberation.

A credible example from Lazarus' first period is Frantz Fanon, a well-known representative of postcolonial theorists of this period. Fanon (1963) wrote The Wretched of The Earth, creating a significant impact on Third World politics. In this book, Fanon mentions that violence is necessary to fight colonialism. Fanon believes that decolonization should always be violent. His view is that indigenous people should embrace great violence to get rid of a violent colonizer. Fanon, therefore, combines nationalism into the context of postcolonial studies in regard to the Third World.

Lazarus (2011) indicates that the second period starts at the end of the 1960s and the beginning of the 1970s, a time he identifies as one of postwar boom. During this period, Lazarus mentions that, "the world-system stumbled into economic recession and attendant political crisis, from which it has yet to recover" (p. 2). At this time, the transition from direct colonization occurred through the establishment of indirect methods of control which created political crises. During the last forty years, economic power has replaced the use of physical force, but this economic power has been wielded towards the corruption and subversion of political systems in the Third World nations. Lazarus (2011) states:

policies formed part of a consolidated attempt on the part of the neo-liberal political elite then rising to hegemony in the core capitalist countries and elsewhere "to overturn rising the limited gains made by working people throughout the world-system in the post-war period'. What was labeled 'globalization' and projected by neo-liberal ideology. (p. 7)

Based on Lazarus's argument, the end result for colonizer/colonized remains consistent between these two periods. The subaltern masses in both periods were silenced and oppressed. In the second period, it is almost the same passivity and oppression that is repeated by the neo-liberal governments, which indicates the indirect colonization. Lazarus (2011) describes the ideology supporting neo-liberal politics as a global strategy which is consciously framed for maintaining inequality of power between the First and the Third World (p. 7). This inequality is then projected onto the political systems developed within the Third World. Lazarus's argument shows that the neo-liberal system repeats the old division of the colonial ideology with a new version that reconstructs a savage relation between masses and the political elites in the Third World.

Political systems within the third world are notoriously skewed in reserving power to a very few. This is by design and in concordance with the neo-liberal agendas. Lazarus (2011) 
discusses the transition of the political state as it was established in the decolonized countries of Africa, Asia, and the Caribbean. Lazarus (2011) notes that the formation of these newly "independent" governments was typically accomplished through negotiation with former colonial rulers (p.10). The case of Kenya forms an apt example for illustrating this. The novel A Grain of Wheat by Ngugi wa Thiong'o (2012), accurately depicts the years after Kenya gained its independence from Great Britain. Ngugi portrays how the Mau Mau Act, as the national liberation movement, succeeded in fighting the British colonial authority and achieving Kenyan independence, a fact which is celebrated in the novel. At the same time, Ngugi (2012) demonstrates how the corruption of the new Kenyan government became a threat for the freedom of the Kenyan masses because it was established under the supervision of the British authority in the first part. Lazarus (2011) explains the situation that follows the decolonization transition from period one to period two, indicating that the same apparatus which had been used to disadvantage the masses in favor of colonial interests were now adopted and used to serve the "new leaders own social and political interests (p. 11). The end result for the broad population in Ngugi's (2012) example, is that the degree of agency has remained unchanged despite moving from one government to another; the subaltern masses remain oppressed and passive. This, in turn, reflects back on the positioning of power described by Said (2003).

If the subaltern masses are to ever move from the subaltern position, the identity of these masses must come to the forefront. Ania Loomba (2005) begins this task by asking these questions: "Are human beings essentially the same or different? Is difference defined primarily by racial attributes?" (p. 91). Developing the thoughts of Abdul JanMohamed, Loomba suggests that the legacy of colonial perspectives is a dire and unbending binary based on the hierarchy of race ( $p$. 91). Loomba discusses how this opposition is fundamental in establishing European identity through differentiating it from foreign Others. In response, Loomba (2005) argues that many anticolonial and postcolonial theorists exposed the ideological and historical function of such binaries as part of building resistance to the subjugation and exploitation of Others. Essentializing binary and racial division was part of the Eurocentric discourse during the colonization period through which the colonizers institutionalized their superiority over the inferior colonized nations. Racism is an ongoing tool that fueled the hegemonic discourse to emphasize the binary division between the White Western race as superior to the Other darker races, which were essentialized as inferior.

Through abstract divisions which were subsequently established as dogma within Eurocentric discourse, the Occidental constructed the Orient, fueling Western hegemonic practice that essentialized division between East and West, just as Said (2003) describes in his theory of Orientalization. Through this division, the Orients were assigned essentialized identities by the Eurocentric discourse that makes them always to be the inferior to the White Western dominance. Recognizing these theoretical points is significant to consider before the departure point, as this paper's argument moves to identify how several literary texts written by Western authors were institutionalized by the hegemonic discourse that essentialized fixed identity for the Orient as inferior.

Arab World English Journal for Translation \& Literary Studies 


\section{Discussion}

The first example is William Shakespeare (1990), who wrote his last play, The Tempest in 1610. His play is one of the significant Western texts that played an essential role in the representation and construction of colonial imperialism. This play represents the Western ideology that represses and exploits the relationship between the protagonist, Prospero, and the antagonist, Caliban. In a sense, this pairing originates the concept of the imperial master and the colonized indigene. The time and space in which the play was performed is the seventeenth century corresponds to the period in which England "discovered" new properties and claimed its first colonial possessions, and this is represented in the play.

Violence is an important aspect of colonial imperialism, which is a concept of representing the uncivilized cannibal indigenous as brutal savages that need to be controlled by violence to be civilized. Susan Bennett (2013) states that the "discursive frames of Caliban's insurgence in The Tempest mark a founding premise of colonialism: that the 'uncivil' may be dispossessed by the 'civil' on the justification of the latter's attempt to 'civilized' the former" (p. 121). Caliban is not just an uncivilized indigene, but he also represents the threat of revolt as Bennett notes that Caliban's uprising is timed to contrast with Prospero at his most "civil," when he is hosting the celebration of the union of Miranda and Ferdinand (p. 121). Therefore, we see in the play several descriptions of Cailban as part of the process of creating a fixed identity for the Orient who is represented as uncivilized, violent Other. Prospero refers to Caliban's efforts as a "foul conspiracy" (Shakespeare, 1990, p. 52).

Despite Caliban's betrayal, Prosper retains efficient surveillance of the colonizer, enabling him to counter threat. Turning to his newly chastised subject, Prospero describes him as: "A devil, a born devil, on whose nature/Nurture can never stick; on whom my pains, /Humanely taken, all, all lost, quite lost" (Shakespeare, 1990, p. 54). Although Caliban's revolt may indicate his resistance to the dominant colonizer, these lines portray the emphasis the colonizer places on describing the brutality of the nonwhite people to justify the colonization of the entire land. Memmi (2013) identifies a theoretical interpretation of such portrayals, saying that "oppression justifies itself through oppression: the oppressors produce and maintain by force the evils that render the oppressed, in their eyes, more and more like what they would have to be like to deserve their fate" (p. xxvi). These lines represent how the Western hegemonic discourse justifies the means of dehumanization of the indigenous by identifying the colonialist apparatus.

Robinson Crusoe represents a similar hegemonic discourse supporting colonialist ideology through the portrayal of minority characters as being uncivilized violent savages. Defoe (1899) wrote the novel during the late seventeenth and early eighteenth centuries, a time of great colonial expansion by Europe. Defoe's text can be read as a representation of the Western institutionalized ideology of creating fixed identities of the Other nations. In his book, Culture and Imperialism, Said (1995) considers Robinson Crusoe as "a concretely historical narrative shaped by the real history of real nations" (p. 77). The relationship between the protagonist, Robinson Crusoe, and the Other indigenous people (Xury, "the Ottoman peasant Arabian" and Friday "the Black African") he meets during his journey represents the colonial approach of creating a fixed identity 
of the Others. Said (1995) describes the Orient as a fantasy of the Occident's ideology of opposing the Other, as a process of the Western imagination on reflecting the Orient as a real thing. Said's argument shows that the Occident essentially controls the identity of Others by initially creating an identity for them through assumed institutions and beliefs. Central to these beliefs is that Eurocentric superiority should be represented over those called "savages."

Robinson Crusoe reflects the Occident ideology and the imagination of the Orient as violent uncivilized cannibals. The novel gives a predetermined identity to the indigenous that represents their threat to the British Empire. During Crusoe's adventures, the brutal Moors enslaved him, but Crusoe is able to rebel and flees with the Moor's servant who belongs to the represented barbaric pirates. Crusoe chooses Xury among those he sees as barbaric and throws the rest of the Moors to the sea because they are a threat to the dominant colonizer. Crusoe enslaved Xury, and Xury's part in becoming civilized is to learn to speak English and to be able to sacrifice his life for Crusoe. In the novel Xury offers: "if Wild mans come, they eat me, you go wey" (Defoe, 1899 , p. 42). The novel represents that part of the Western civilization under the colonization mission is to create a concept in the Oriental mind, as the case with Xury, that the White man is superior over all others.

The same ideology is repeated with Crusoe and Friday's relationship as master and slave. Crusoe asks Friday to call him "Master" as a process of maintaining his superiority over him. Crusoe also creates a new identity for Friday, initially by changing his name, and then by teaching him some English words as part of the process of civilizing him. At the same time, he uses him to fight threats to his domination by using him to kill the rest of indigenous people who are portrayed as cannibals. Therefore, Robinson Crusoe represents how the Western novelist started to institutionalize the Eurocentric discourse that essentialized fixed identities of the Orient as violent uncivilized beings who should be considered inferior to white dominance.

A similar scenario supporting Eurocentric hegemony is repeated in the nineteenth century, with a different perspective. Charlotte Bronte (2011), chooses to combine gender and the racial violence of Others through her minority character, Bertha, in her novel, Jane Eyre. Susan Meyer (1990) argues that, Bronte's novel includes an "implicit critique of British domination," something which the romantic elements of the plot fail to hide (p. 250).

Bronte gives Bertha a silent role with much description of her physically "savage face," a characteristic based on the color of her skin, as well as her violent actions, driven by her madness. Meyer (1990) discusses the significance of colonialism in the novel as she quotes Spivak's (1988) claim about Jane Eyre as, "the unquestioned ideology of imperialist axiomatic" (p. 250); Meyer (1990) argues that Bronte's narrative enables the individualistic social progress of the character Jane Eyre to be celebrated by the mainstream feminists (p. 250). At the same time, Bronte portrays Bertha as "white Jamaican Creole," and, as such, she is represented in the novel as a "native subject" who is excluded from the individualistic humanity that Western feminists claimed for Jane (p. 250). Therefore, the identity of Bertha as a "Creole" further represents the Eurocentric 
discourse to create a significant division that represents the superiority of the Whites over the other races.

Bronte represents Bertha as the source of tension based on her physical appearance as being the Other. It is significant that her madness is linked to her non-English heritage. Therefore, she is represented as a violent savage who burns the house and kills herself. Her husband, Rochester, confirms this attitude as he exclaims of Bertha that, "she came of a mad family; idiots and maniacs through three generations! Her mother, the Creole, was both a madwoman and a drunkard!" (Bronte, 2011, p. 366). In another quote, Jane clearly describes Bertha's face as a way which reflects the ideology of racial Otherness. Jane tells Rochester: "It was a discolored face - it was a savage face. I wish I could forget the roll of the red eyes and the fearful blackened inflation of the lineaments!" (Bronte, 2011, p. 172). Adding to these descriptions, the violent act by Bertha as she sets the house on fire, trying to kill Mr. Rochester, represents the Western ideology of recognizing the Orients as aggressive violent savages who are essentialized as a threat to the colonial domination.

These same trends continue into the twentieth century. A similar Western ideology, in which minority characters are still portrayed as violent, savage and uncivilized is evident in the work of E. M. Forster. Forster is another English author who wrote A Passage to India in 1924 during the period of undisputed British colonial rule in the Indian subcontinent. Based on Said's (1995) Orientalist discourse, this novel represents how Forster, as a British writer, portrays the colonialist ideology that emphasizes on the superiority of the white race by essentiaizing an inferior identity of the Indians to the dominant British. Forster represents the relationship between the Indians and the British as unreliable and unpredictable because of what Said describes as a repetition of the Orientalist construction of stereotype. The concept of the Orient identity as essentialized by the Western ideology is less and should be inferior to the dominant Occident. Therefore, we see in the novel that Ronny, the British magistrate, is unhappy with the educated Indians, as the case with Dr. Aziz.

A Passage to India represents the Western ideology of portraying the Orient as barbaric, violent beasts. In it, Dr. Aziz is depicted as untrusted by the British authority despite his best attempts to please the British. The best example is his journey to the Marabar Caves with Mrs. Moore and Ms. Adela Quested. Aziz is accused of sexual harassment against Adela, and he is represented to entire nation as a horrible sexual beast. Although Dr. Aziz is innocent, this situation represents the British imperialist ideology toward the Indians, as the Orients, who are essentialized as a source of danger, something suspect because it is not British. The purpose for this is to constantly emphasize the binary of being and the hierarchy it suggests. Said (1995) identified such Western ideology as a way "to note how the 'East' has always signified danger and threat" (p. 26). At the same time, in the novel, Dr. Aziz is represented as without agency, as passive, since he is not able to present an authentic proof of his innocence; instead, his innocence is signified through "Oriental Silence".

Arab World English Journal for Translation \& Literary Studies 
The novel indicates the British superiority over the Indians, and therefore, it is difficult to have a relationship between the Orient and the Occident. Forster ends the novel with Fielding's conversation with Aziz about this matter: "Why can't we be friends now?" (Forster, 1969, p. 289). Despite their mutual desire to do this, the answer is, "No, not yet" (p. 289). Said (1995) describes this conversation as "a sense with the pathetic distance still separating 'us' from the Orient destined to bear its foreignness as a mark of its permanent estrangement from the West" (p.244). I believe that Forster's novel interprets the colonial imperialist ideology that emphasizes on the danger of the violent Orient who may not be trusted as a friend to the Occident.

Spivak (1988) follows Said's Orientalism suggesting that imperialist ideology was the essential element allowing dominant powers to successfully subjugate peoples who were passive and silent. Spivak goes beyond Said by focusing on the less privileged sectors of the colonized people. Spivak's point is that she wants to give the silenced Others a voice to speak. Spivak (1988) concludes her essay "Can the Subaltern Speak" by stating that the ultimate answer is, no. (p. 104). She discusses how the colonizer disfigured the history and culture of the colonized. Spivak portrays her analysis of silencing of the subaltern by the Western radical intellectuals. Therefore, Spivak raises a challenge that emphasizes the role of intellectuals, in which she suggests that they should avoid denying any legitimacy when representing the oppressed subaltern.

In response to the history of imperial, Eurocentric hegemonic ideology being supported and replicated in European literature, postcolonial critics and minority authors try to challenge and resist the hegemonic discourse by writing back to represent thoughts that resist the Western hegemonic discourse that essentialized the identity of the Orient. Third World postcolonial authors who respond to such representation are divisible into two groups, those who have been successful and those who have failed in their aims.

Among postcolonial authors, Aimé Césaire (1974) and Jean Rhys (1966) are postcolonial authors who succeed in responding to the Eurocentric discourse of representing the Others as savages who should be considered inferior and are, therefore, subject to White dominance. Césaire wrote A Tempest in 1969 as a response to Shakespeare's portrayal of Caliban as a violent savage. Smith and Hudson (1992) claim that in Césaire's work, Caliban only seems to be savage because that is what Prospero expects, but, "in reality, he is a trickster and a shrewd, impatient slave who refuses to submit and a who wants freedom without delay" (p. 387). The authors' argument shows that Césaire did not deny the savagery of Caliban. But they gave Césaire credit for depicting Caliban as "not passive and obedient as some would have him be" (Smith \& Hudson, 1992, p. 387). In this, Césaire is successful in his response to the Western ideology which would operate through silencing Caliban. For example, in Césaire's play, Caliban can speak and his first word early in the play is "Uhuru" (Césaire, 1974, p. 24). This word means a fight for freedom, a Swahili word used also in Ngugi's (2012) A Grain of Wheat by Kikuyu tribe during the British colonization as a call for their liberty. Therefore, Césaire is giving Caliban the agency to speak for himself to represent his thirst for his liberty from Prospero "the colonizer".

Arab World English Journal for Translation \& Literary Studies 
Smith and Hudson (1992) claim that Césaire represents Caliban's as a Third World hero, and that this has become a metaphor recognized within the genre where "a totalitarian Prospero" must be countered by is "an antiauthoritarian Caliban" (p. 394). Therefore, Césaire is decidedly successful in constructing agency for the silenced Caliban. He also a successful in interpreting Caliban's acts of violence as heroic, as the means though which Caliban was trying to attain his freedom from the legacy of colonialism. Smith and Hudson (1992) claim that, "Césaire now, like Shakespeare before him, is a perpetual subject for literary criticism and contemporary theories" (p. 388). Césaire is successful because he resists the hegemonic ideology of the imperialist colonizer, and because he altered the centuries-old significance evoked by the name Caliban

Jean Rhys (1966) is another postcolonial author who also succeeds in resisting the hegemonic discourse that silenced Others. She wrote her novel The Wide Sargasso Sea in 1966 and constructed agencies for race and gender identified as double oppression by feminist postcolonial studies. Rhys succeeds in constructing a postcolonial, resistant text that challenges Western ideology. In the novel, Rhys allows Antoinette to speak for Bertha who was silenced and represented as a violent mad woman in Bronte's Jane Eyre. Rhys succeeded in bringing to life the silenced moments in Bertha's life. Rhys develops psychological reasons that explain the madness that drives Bertha to act violently, something which Bronte dismisses as passively inherited form her family. The Wild Sargasso Sea responds to such claims, showing how colonial oppression created social struggle and a legacy that impacted Antoinette and her mother physically and psychologically, leading them to act violently, something which is interpreted as an act of resistance. Antoinette's mother, Annette, violates the colonialist ideology through her race, class, and sexuality, as Rhys begins the novel stating that, "They say when trouble comes close ranks, and so the white people did. But we were not in their ranks" (Rhys, 1966, p. 17). Despite this positioning as Other, Ryes succeeds by resisting the Eurocentric discourse that silences Others.

While successful on the count of giving voice to the voiceless, Rhys failed to represent the impact of the colonial impartiality in creating racial and social division among the West Indians. In her article, Carine M. Mardorossian (1999) discusses Rhys' description of West Indian social and racial relations in The Wide Sargasso Sea. Mardorossian (1999) is concerned with how Antoinette is represented as "the white Creole protagonist" (p. 1071). For Mardorossian, this categorization mires Antoinette in the colonial discourse, establishing her position in relation to indigene and colonizer (p. 1071). This plays closely into recognized binary patterns, complicating viewing the protagonist as resistant to these binaries. The novel represents the social and racial tension between the black Creoles and white Creoles, as seen in the relationship between Christophin and Antoinette. Rhys does succeed in her response to the Eurocentric discourse that silences the Others and represent them as savages. At the same time, Rhys fails to resists the Eurocentric discourse that essentialized fixed identities even among the indigenous, black Creoles and white Creoles, which can be interpreted as way of maintaining their superiority over the unstable society.

Tsitsi Dangarembga (1988) is another postcolonial author who fails to challenge the Eurocentric discourse that has essentialized the inferiority of dark nations to the dominant White 
superiority, as she represents the dominant culture of the oppressors as a desirable ideal society. Instead of identifying the reasons of structural violence among members of her society, Dangarembga wrote her novel, Nervous Conditions in 1988, as a depiction of Tambu's struggling amid Zimbabwean structural violence, especially as exemplified by Babamukuru, her uncle who aggressively had silenced and controlled her life.

David Aberbach (2004) argues how, "[a] persecuted minority that see dominant culture... as a superior, desired ideal, a possible way out of social and cultural entrapment, is highly vulnerable to confusion in social relation and cultural values, acute self-criticism and disillusionment" (p. 214). I believe that Dangarembga (1988) is entrapped by Western ideology in her novel, in which Tambu the narrator seems to reject her own identity as she is discouraged by her native language and culture. This attitude extents to her own family; Tambu is harsh during the moments when she opens the novel saying, "I was not sorry when my brother died" (p. 1). Dangarembga fails to pay much attention to the pressure on her society under the colonial oppression that creates poverty and lack of education. Aberbach (2004) argues that, "[i]n Nervous Condition, education heightens awareness of how white control over labor and land determines social relations between Black and Whites and corrupts their institutions, beliefs and values" ( $p$. 222). Even though Dangarembga's novel highlights the need of education for social conscious, the author fails to challenge the Western ideology that represents her and her nation as being inferior to the dominant society.

Finally, The Reluctant Fundamentalist by Mohsin Hamid (2012), a $21^{\text {st }}$ century postcolonial author, who also fails to challenge the Eurocentric discourse that has essentialized the inferiority of Orient. The novel's protagonist, Changez, represents the impact of 9/11 attacks on his life as a Pakistani migrant who feels isolated by the Americans. For example, Changez portrays his feelings after watching the 9/11 attacks with a sense of being guilty during the time he leaves Manila returning to America. Changez states: "I flew to New York uncomfortable in my own face" (Hamid, 2012, p. 74). The novel might seem to be resistant to racism and Othering, which has increased due to the war and terror, but, if so, how does Hamid resist the Western ideology of stereotyping that he attempts to challenge?

Hamid's failure might come from the representation of his internalized concept of the Eurocentric discourse that stereotypes the Orient whose violence is a threat to Western dominance. Therefore, the reader sees Changez, as the narrator, is inferior to Western superiority, positioning the character within the traditional binary of colonial ideology. Hartnell (2010) states that, "[a]rguably The Reluctant Fundamentalist itself fails to escape the stereotypes it erects and attempts to challenge" (p. 337). In her argument, Hartnell claims that through Orientalist stereotypes, Hamid establishes his novel in a way that makes US imperial power heir to the European colonial legacy. Therefore, Hamid is like other postcolonial authors who fail to challenge the Eurocentric discourse to resist the Western institutionalized concept that represents the violent Orient is always the source of threat to the white dominance.

Arab World English Journal for Translation \& Literary Studies 


\section{Conclusion}

Based on the provided discussion, examples, and argument, it is clear that postcolonial authors still need to challenge the Eurocentric discourse that represents the Occident as civilized dominant and dehumanized the Orient as violent savage. The portrayal of minority characters as violent savages extends over span of three centuries, pre-colonial, colonial, and post-colonial eras, starting from Shakespeare's (1990) The Tempest to E. M. Forster's (1985) A Passage to India. Commonalities exist among Western writers who have supported the same Eurocentric discourse, demonstrating continuity of ideology developed along binary lines to support a hierarchy of identities. In response, some postcolonial authors like Césaire (1974) and Rhys (1966) succeed to challenge and resist the Eurocentric discourse by writing back and constructing agencies for the silenced minorities. And some others, like Dangarembga (1988) and Hamid (2012), also tried to fight back but they fail because they decline to challenge the Eurocentric discourse. Instead, their texts indicate that minority protagonists accept the same ideology as Western authors, demonstrating a feeling of the being inferior to the Eurocentric dominance. Therefore, I join Spivak's (1988) call that requires postcolonial intellectual, scholars, and critics to keep challenging the radical Western ideology and avoid denying any legitimacy when representing the oppressed subaltern.

\section{About the author:}

Dr. Almenia Received his PhD in English Literature \& Criticism in 2017 from Indiana University of Pennsylvania, Indiana, PA. USA. His MA was in English Literature in 2012 from Murray State University, Murray, KY. USA. He is an Assistant Professor of English Literature \& Criticism at the Department of English Language and Translation at Qassim University.

\section{References}

Aberbach, D. (2004). Enlightenment and Cultural Confusion: Mendele's" The Mare" and Dangarembga's "Nervous Conditions." Comparative Literature Studies, 41(2), 214-230.

Bennett, S. (2013). Performing Nostalgia: Shifting Shakespeare and the Contemporary Past. London: Routledge.

Brontë, C. (1850). Jane Eyre: An Autobiography. London: Smith, Elder and Company.

Césaire, A. (1992). A Tempest: Based on Shakespeare's The Tempest: Adaptation for a Black

Theatre. New York: Theatre Communications Group.

Dangarembga, T., \& Daniel, S. (1988). Nervous Conditions. London: Women's Press.

Defoe, D. (1994). Robinson Crusoe. 1719. London: Warne.

Fanon, F., Sartre, J. P., \& Farrington, C. (1963). The Wretched of the Earth. New York: Grove Press.

Forster, E. M. (1969). A Passage to India. Delhi, India: Pearson Education India.

Gramsci, A. (1971). Selections from the Prison Notebooks of Antonio Gramsci. Ed. and Transl. by Quintin Hoare and Geoffrey Nowell Smith. London: Lawrence and Wishart.

Hamid, M. (2012). Reluctant Fundamentalist. Oxford: Oxford University Press.

Hartnell, A. (2010). Moving Through America: Race, Place and Resistance in Mohsin Hamid's The Reluctant Fundamentalist. Journal of Postcolonial Writing, 46(3-4), 336-348. 
Hogan, P. C. (2000). Colonialism and Cultural Identity: Crises of Tradition in the Anglophone Literatures of India, Africa, and the Caribbean. Albany: SUNY Press.

Lazarus, N. (2011). The Postcolonial Unconscious. Cambridge: Cambridge University Press.

Loomba, A. (2007). Colonialism/Postcolonialism. Longdon: Routledge.

Mardorossian, C. M. (1999). Shutting Up the Subaltern: Silences, Stereotypes, and DoubleEntendre in Jean Rhys's Wide Sargasso Sea. Callaloo, 22(4), 1071-1090.

Memmi, A. (2013). The Colonizer and the Colonized. London: Routledge.

Meyer, S. L. (1990). Colonialism and the Figurative Strategy of Jane Eyre. Victorian Studies, 33(2), 247-268.

Ngugi, W.T. (2012). A Grain of Wheat. New York: Penguin.

Rhys, J. (1992). Wide Sargasso Sea. New York: W.W. Norton \& Company.

Said, E. W. (2012). Culture and Imperialism. New York: Vintage.

Said, E. W. (1995). Orientalism: Western Conceptions of the Orient. 1978. Harmondsworth, UK: Penguin.

Shakespeare, W. (1999). The Tempest. London: A\&C Black.

Smith, R. P., \& Hudson, R. J. (1992). Evoking Caliban: Césaire's Response to Shakespeare. CLA Journal, 35(4), 387-399.

Spivak, G. C. (1988). Can the Subaltern Speak? In R. Morris (Ed.), Can the Subaltern Speak? Reflections on the History of an Idea (21-78). New York: Columbia University Press. 